\title{
Disseminated cryptococcosis with varicella-zoster virus coinfection of idiopathic CD4 + T lymphocytopenia: a case report and literature review
}

\author{
Li Fang, Junli Zhang and Fangfang LV ${ }^{*}$
}

\begin{abstract}
Background: Idiopathic CD4 + T lymphocytopenia (ICL) is a rare immunodeficiency syndrome, unaccompanied by various opportunistic infections. Cryptococcus and varicella-zoster viruse are the most common opportunistic infections.

Method: We described a case of disseminated cryptococcosis with varicella-zoster virus coinfection in a patient with $\mathrm{ICL}$ and reviewed all published reports. A total of 26 cases with cryptococcal meningitis in ICL were enrolled.

Discussion: ICL remains poorly understood to clinicians. Patients with cryptococcal meningitis in ICL mostly suffered with headache and fever in a subacute or chronic period, while some patients might have atypical manifestations which makes a difficulty for early diagnosis. Some characteristics of cerebrospinal fluid can help to predict the prognosis of the disease. Cryptococcosis with varicella-zoster virus coinfection is rare but serious.

Conclusion: We recommed CD4 $+T$ cells should be assessed in patients with unusual or recurrent infections. As the underlying pathophysiology is poorly understood, there is no standard therapy for ICL. Increased awareness of the disease and early prevention for CD4 reduction are needed.
\end{abstract}

Keywords: Cryptococcosis, Cryptococcal meningitis, Varicella-zoster virus, Idiopathic CD4+T lymphocytopenia

\section{Background}

Idiopathic $\mathrm{CD} 4+\mathrm{T}$ lymphocytopenia (ICL) is a rare immunodeficiency syndrome with an unexplained reduction of CD4 + T lymphocytes and no evidence of Human Immunodeficiency Virus (HIV) infection or any other cause of immunodeficiency [1]. It is defined as a documented absolute CD4+T-cell count $<300$ cells/L or $<20 \%$ of total lymphocytes on at least two occasions, usually two or three months apart [2]. Patients with ICL typically present with opportunistic infections, malignancies,

\section{*Correspondence: Ivfangfang@zju.edu.cn}

Department of Infectious Disease, Sir Run Run Shaw Hospital, School of Medicine, Zhejiang University, 3 Qingchun East Road, Hangzhou 310020, China or autoimmune disorders. Cryptococcus infection is the most common opportunistic infection in ICL patients [1]. Cryptococcal meningitis is the most serious disease with high morbidity and mortality [3-5]. Here, we present a case of disseminated cryptococcosis with varicellazoster virus coinfection in a patient with ICL, and the relevant literature is reviewed. ICL should not be ignored in some patients who seem to be immunocompetent.

\section{Case presentation}

A 44-year-old man was admitted to the emergency department with a complaint of headache lasting for 10 days without fever or any other symptoms, and he was prescribed some painkillers. He suffered fever, vomiting, 
delirious and urinary retention two weeks later. He had no medical or surgical history and no history of drug or alcohol abuse. Vital signs included a body temperature of $38.5{ }^{\circ} \mathrm{C}$, respiration of 20 breaths $/ \mathrm{min}$, heart rate at 97 beats/min, blood pressure of $133 / 90 \mathrm{mmHg}$, and $\mathrm{O}_{2}$ saturation of $97 \%$ on ambient air. Physical examination showed a decreased muscle strength of both lower limbs and neck was stiff with positive Kernig's and Brudzinki's signs.

Laboratory tests results are as follows: a leukocyte count of $15.3 / \mathrm{mm}^{3}$ (reference range $3.5-9.5 / \mathrm{mm}^{3}$ ), with neutrophils $14.18 / \mathrm{mm}^{3}$ (reference range $1.8-6.3 / \mathrm{mm}^{3}$ ) and lymphocytes $0.5 / \mathrm{mm}^{3}$ (reference range $1.1-3.2$ / $\mathrm{mm}^{3}$ ), high-sensitive c-reactive protein $26.5 \mathrm{mg} / \mathrm{L}$ (reference range $0-5 \mathrm{mg} / \mathrm{L}$ ), Erythrocyte Sedimentation Rate $46 \mathrm{~mm} / \mathrm{h}$ (reference range $0-20 \mathrm{~mm} / \mathrm{h}$ ), potassium $2.95 \mathrm{mM} / \mathrm{L}$ (reference range $3.5-5.5 \mathrm{mM} / \mathrm{L}$ ), sodium $132 \mathrm{mM} / \mathrm{L}$ (reference range 137-147 $\mathrm{mM} / \mathrm{L}$ ), chlorine $92 \mathrm{mM} / \mathrm{L}$ (reference range $99-110 \mathrm{mM} / \mathrm{L}$ ), and serum creatinine $163 \mu \mathrm{M} / \mathrm{L}$ (reference range $40-106 \mu \mathrm{M} / \mathrm{L}$ ). The biochemistry testing on the liver was normal. A lumbar puncture (LP) showed an elevated open pressure of
$>40 \mathrm{cmH}_{2} \mathrm{O}\left(1 \mathrm{cmH}_{2} \mathrm{O}=0.1 \mathrm{kPa}\right)$. Cerebrospinal fluid (CSF) analysis revealed $90 / \mathrm{mm}^{3}$ leukocyte (reference range $0-5 / \mathrm{mm}^{3}$ ), with $9 \%$ neutrophils and $86 \%$ lymphocytes. The glucose level was $0.28 \mathrm{mM} / \mathrm{L}$ (reference range 2.5-4.44 mM/L), chloride level was $116 \mathrm{mM} / \mathrm{L}$ (reference range $119-129 \mathrm{mM} / \mathrm{L}$ ) and protein level was $0.898 \mathrm{~g} / \mathrm{L}$ (reference range $0.15-0.45 \mathrm{~g} / \mathrm{L}$ ). Polymerase chain reaction (PCR) for Herpes simplex, Epstein Barr virus, Varicella, Cytomegalovirus were negative. Acid-fast staining was negative, India ink preparation was positive, and cryptococcal antigen showed positive at $76.6 \mu \mathrm{g} / \mathrm{L}$. The mycological culture was positive for Cryptococcus neoformans variant. A head computed tomography (CT) scan revealed no signs of hydrocephalus. The electroencephalogram showed a minor anomaly, while a lung CT scan revealed cavernous lesions in the lower lobe of the left lung, and pleural effusion was observed bilaterally, as well as a few fibrous foci in the right lung's middle lobe (Fig. 1).

A thorough analysis to rule out immunocompromised status was performed. The HIV serology and HIV RNA, T-SPOT.TB tests were negative, the antinuclear antibody
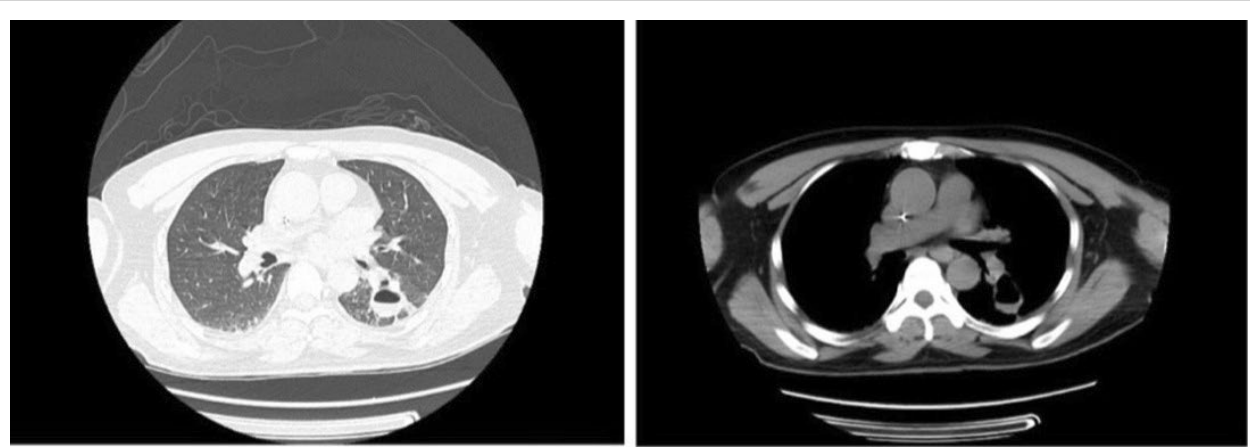

Fig. 1 Lung CT scan revealed cavernous lesions in the lower lobe of the left lung and a few fibrous foci in the right lung's middle lobe, as well as a minor amount of pleural effusion

Table 1 Blood cell counts of the patient with CD4 + T lymphocytopenia

\begin{tabular}{|c|c|c|c|c|c|c|}
\hline \multirow[t]{2}{*}{ Date of analysis } & \multicolumn{6}{|l|}{ Count, $/ \mathrm{mm}^{3}$} \\
\hline & $\begin{array}{l}\text { white blood } \\
\text { cells 3.5-9.5 }\end{array}$ & $\begin{array}{l}\text { Lymphocytes } \\
1.1-3.2\end{array}$ & $\begin{array}{l}\text { CD3 + CD4+ cells } \\
0.20-1.82\end{array}$ & $\begin{array}{l}\text { CD3 }+ \text { CD8 + cells } \\
0.13-1.35\end{array}$ & $\begin{array}{l}\text { CD16/56+ cells } \\
0.04-1.00\end{array}$ & $\begin{array}{l}\text { CD19+ cells } \\
0.05-0.67\end{array}$ \\
\hline March 27 & 9.6 & 0.4 & 0.04 & 0.18 & 0.02 & 0.17 \\
\hline April 6 & 7.7 & 0.5 & 0.06 & 0.26 & 0.01 & 0.1 \\
\hline April 26 & 4.4 & 1.0 & 0.12 & 0.71 & 0.03 & 0.04 \\
\hline June 29 & 6.5 & 1.5 & 0.18 & 0.84 & 0.04 & 0.28 \\
\hline
\end{tabular}

CD16/56+ cells : natural killer cells, CD19+ cells ${ }^{*}: B$ cells 
was negative, and the serum immunoglobulins and complement were normal. The anti-IFN- $\gamma$ autoantibodies linked to disseminated nontuberculous mycobacterial infections were normal. He had serially decreased lymphocytes during his follow-up, particularly CD $4+\mathrm{T}$ cells in Table 1.

The patient was treated with amphotericin $B(0.7 \mathrm{mg} / \mathrm{kg}$ daily) and 5-fluorocytosine ( $2.5 \mathrm{~g}$ per $12 \mathrm{~h}$ ), an Ommaya reservoir was implanted for cerebrospinal fluid drainage. He was deteriorated in the second week of hospitalization, with persistent positive CSF culture and a higher CSF cryptococcal antigen result $(3097.6 \mu \mathrm{g} / \mathrm{L})$. During the fourth week of hospitalization, zonal dispersed papules were seen on the right lower leg of the patient, with reduced muscular strength in both lower limbs, and he was suffered from hallucinations and auditory hallucinations. Cerebrospinal fluid was hemorrhagic, with $6 /$ $\mathrm{mm}^{3}$ leukocyte and $700 / \mathrm{mm}^{3}$ erythrocyte. Magnetic resonance imaging (MRI) showed multiple lesions and lamellar necrosis in the parietal lobe of the frontotemporal island and the cortex of the left cerebellar hemisphere. We also observed hydrocephalus in several lesions, accompanied by interstitial edema (Fig. 2). Varicella-zoster virus and cryptococcus were positive in metagenomic next-generation sequencing (mNGS) of cerebrospinal fluid, and ganciclovir was started for antiviral therapy. Unfortunately, he finally died of cerebral edema and respiratory failure after 3 months of admission.

\section{Literature review and discussion}

ICL is a rare condition that is found worldwide, with unknown incidence and etiology, and it is viewed as a syndrome that likely encompasses different disorders caused by the reduction of CD4 cell numbers. CD4 is a glycoprotein expressed on the surface of various types of helper and regulatory $\mathrm{T}$ cells. $\mathrm{CD} 4+\mathrm{T}$ cell is an important immune cell that regulates the activities of cells participating in immune responses, participate in apoptosis (programmed cell death), and tumor monitoring. Patients with ICL will develop opportunistic infections, malignancies, and/or autoimmune diseases [6]. Cryptococcal meningitis is the most common opportunistic infection. According to a series of studies, one-third of patients were infected with cryptococcus, while around $10 \%$ were infected with the varicella-zoster virus [7]. Cryptococcus was reported to be the most frequent infection in 258 ICL patients $(26.6 \%)$, followed by mycobacterial (17.0\%), candidal (16.2\%), and varicella-zoster virus infections (13.1\%) [8].

$\mathrm{CD} 4+\mathrm{T}$ cells should be assessed when the patient presents with unusual or recurrent infections. However, the infection can be associated with lymphocyte changes, and it is impossible to determine whether changes reflect a primary immunologic defect or the response to infection. Our patient suffered disseminated cryptococcal infection and herpes virus infection with no underlying disease and HIV or tuberculosis, but a series of low CD4+ T

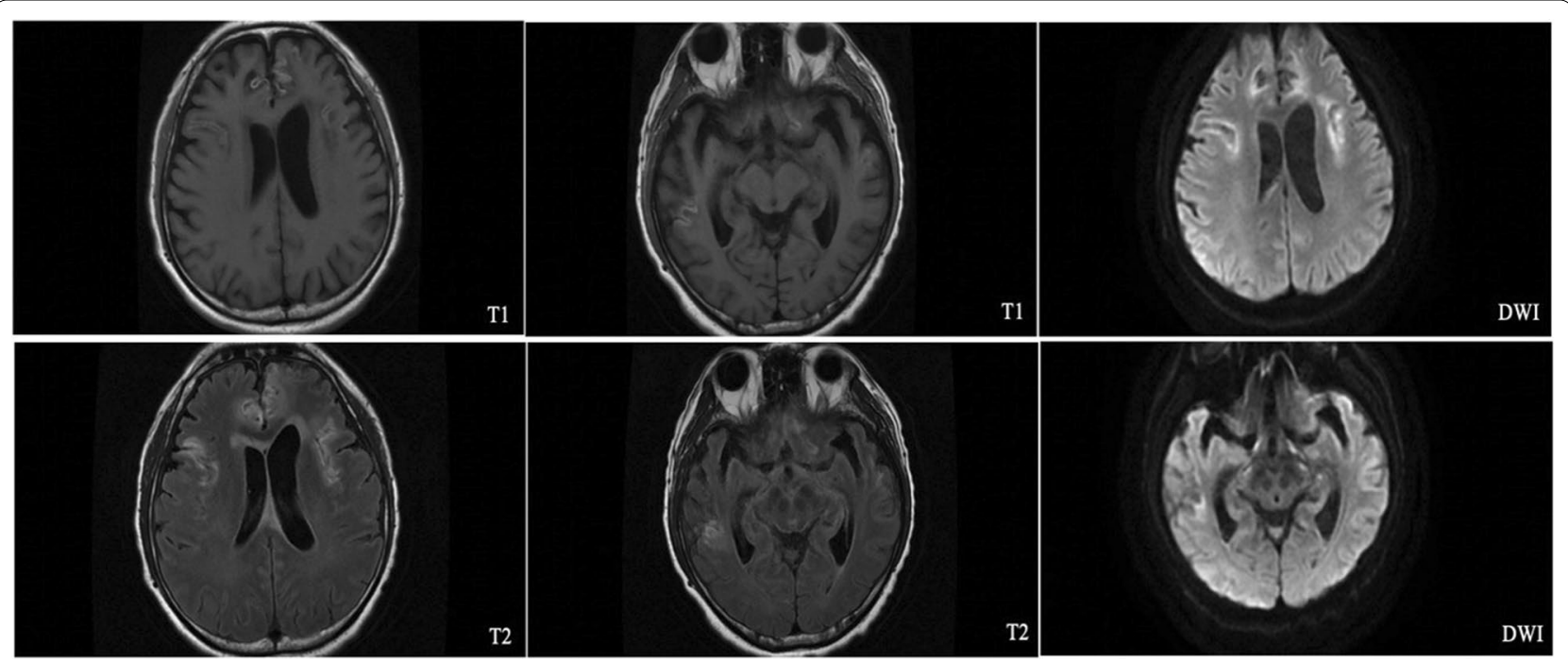

Fig. 2 Brain MRI scan revealed multiple lesions and lamellar necrosis in the parietal lobe of the frontotemporal island and the cortex of the left cerebellar hemisphere, also we observed hydrocephalus in several lesions, accompanied by interstitial edema 
cells lasting for more than 3 months. As reported, anticytokine autoantibodies have also been related to opportunistic infections, with anti-IFN $\gamma$ autoantibodies linked to disseminated nontuberculous mycobacterial infections and anti-IL-17 autoantibodies linked to chronic mucocutaneous candidiasis, and anti-IL-6 autoantibodies linked to Staphylococcal infections [9]. Anti-GM-CSF autoantibodies have also been found in a few cryptococcal meningitis patients caused by Cryptococcus. Gattii, but not Cryptococcus. neoformans $[10,11]$. However, CD $4+\mathrm{T}$ cells were normal or slightly lower in most patients [12].

Cryptococcal meningitis is not uncommon in the clinic, and ICL remained poorly understood to clinicians. There are few systematic reviews on ICL and cryptococcal meningitis. A systematic search was performed on PubMed between 1992 and December 2020. A combination of the following search terms was used: cryptococcosis, cryptococcus infection, cryptococcal meningitis, idiopathic CD4 lymphocytopenia, ICL, HIV negative CD4 lymphocytopenia. 26 cases were enrolled for analysis [13-36]. Among those patients, 20 (76.9\%) were male, $6(23.1 \%)$ were female. The median age was 42 (range 4.5-75) at diagnosis. Cryptococcosis in ICL patients usually had a subacute or chronic course and took weeks to months from symptom until diagnosis [37]. The most common symptoms were headache, fever, nausea/vomiting, and meningeal irritation. The symptoms in those 26 patients were described in Table 2 . The primary symptoms were headache and fever $(73.1 \%, 61.5 \%)$. Nausea, vomiting, and disorientation were also common. The patients suffered only headaches at the early period.

Table 2 Presenting Symptoms of cryptococcal meningitis in ICL

\begin{tabular}{lc}
\hline Symptoms & No. of patients (\%) \\
\hline Headache & $19(73.10)$ \\
Fever & $16(61.50)$ \\
Nausea/vomiting & $9(34.60)$ \\
Confusion & $8(30.80)$ \\
Dizziness & $4(15.40)$ \\
Neck pain & $3(11.50)$ \\
Hemiparesis & $3(11.50)$ \\
Ataxia & $3(11.50)$ \\
Weight loss & $3(11.50)$ \\
Diplopia & $3(11.50)$ \\
Experiencing speech difficulties & $2(7.70)$ \\
\hline
\end{tabular}

Therefore, some patients might have atypical manifestations during the process of disease.

Cerebrospinal fluid were analysed in 22 cases with adequate information in Table 3 [13-19, 21-24, 26, 27, $29,31-36]$. It showed a median leukocyte of 61 cells/ $\mu \mathrm{L}$ (ranging $0-700$ ), mainly constituted by lymphocytic, glucose of $39.1 \mathrm{mg} / \mathrm{dL}$ (ranging 1.98-87 mg/dL), below $40 \mathrm{mg} / \mathrm{dL}(1 \mathrm{mM} / \mathrm{L}=18 \mathrm{mg} / \mathrm{dL})$ in $50 \%$ of the patients, and protein of $116 \mathrm{mg} / \mathrm{dL}$ (ranging $20-266 \mathrm{mg} / \mathrm{dL}$ ). The India ink stain and cryptococcal antigen titer positive rates were $12 / 14(86 \%)$ and $15 / 16(94 \%)$, respectively. The positive rate of CSF culture was 18 /19 (95\%), Only one case was Cryptococcus. gattii and all the others were Cryptococcus neoformans. Cryptococcal meningitis is linked to a high rate of morbidity and death. Poor outcomes have previously been linked to advanced age ( $\geq 60$ years), solid malignancy, hematologic malignancy, liver cirrhosis, respiratory failure, long-term ICU stay, corticosteroid treatment, and disturbed mental state (coma, seizure, herniation) [38-41]. Low CSF leukocyte counts (less than 20 cells/microL), low CSF glucose, high CSF CrAg titers (>1:1024), high CSF opening pressure $\left(\geq 250 \mathrm{~mm} \mathrm{H}_{2} \mathrm{O}\right.$ ), lower Glasgow Coma Scale (GCS) scores, hematogenous dissemination of cryptococcosis, hydrocephalus, and cerebral infarction have all been linked to poor outcomes [38, 40-46].

Cryptococcal infection and ICL have an increased likelihood of developing dermatomal zoster [47]. However, due to a lack of systems analysis, it is not sure whether this coinfection can be more severe than a single infection. We consider the deterioration of our patient is related to the activation of the varicella-zoster virus. We believe it may also require more cases or literature reviews.

\section{Conclusion}

Low $\mathrm{CD} 4+\mathrm{T}$ cell counts characterize idiopathic $\mathrm{CD} 4+\mathrm{T}$ lymphocytopenia and commonly presents as various opportunistic infections, autoimmune diseases, and/or neoplasias. Patients with opportunistic infections with HIV negative should be evaluated for ICL. Here we present a case of disseminated cryptococcosis with varicella-zoster virus coinfection, with an adverse outcome. As the underlying pathophysiology is poorly understood, there is no standard therapy for ICL. The focus is still on the preventive treatment of $\mathrm{CD} 4+\mathrm{T}$ cell reduction. 
Table 3 Presenting characteristics in cerebrospinal fluid of cryptococcal meningitis in ICL patients

\begin{tabular}{|c|c|c|c|c|c|c|c|}
\hline References & Protein $(\mathrm{mg} / \mathrm{dL})$ & Glucose (mg/dL) & $\begin{array}{l}\text { Leukocyte } \\
\text { (cells } / \mathrm{mm}^{3} \text { ) }\end{array}$ & Predominant cell & India ink stain & $\begin{array}{l}\text { Cryptococcal } \\
\text { antigen }\end{array}$ & Culture \\
\hline Sim et al. [13] & 266 & 1.98 & 10 & NA & Positive & $1: 2560$ & $\begin{array}{l}\text { Cryptococcus } \\
\text { neoformans }\end{array}$ \\
\hline Eshwara et al. [14] & 50 & 60 & 54 & Lymphocyte & Positive & Negative & Cryptococcus gattii \\
\hline Malone et al. [15] & 48 & 87 & 45 & Lymphocyte & Positive & $1: 512$ & $\begin{array}{l}\text { Cryptococcus } \\
\text { neoformans }\end{array}$ \\
\hline Shribman et al. [17] & 83 & 34.2 & NA & Lymphocyte & NA & $1: 1280$ & $\begin{array}{l}\text { Cryptococcus } \\
\text { neoformans }\end{array}$ \\
\hline Shribman et al. [17] & 89 & 19.8 & 212 & Lymphocyte & NA & Positive & $\begin{array}{l}\text { Cryptococcus } \\
\text { neoformans }\end{array}$ \\
\hline Ivica et al. [18] & 138 & 66.6 & 478 & Neutrophils & Positive & NA & $\begin{array}{l}\text { Cryptococcus } \\
\text { neoformans }\end{array}$ \\
\hline Sancesario et al. [19] & 133 & 23 & 23 & NA & Negaitive & NA & NA \\
\hline Sharma et al. [21] & 125 & 17 & 0 & 0 & NA & $1: 8192$ & $\begin{array}{l}\text { Cryptococcus } \\
\text { neoformans }\end{array}$ \\
\hline Augustine et al. [22] & 107 & 31 & 125 & Lymphocyte & Negative & NA & negative \\
\hline Augusto et al. [23] & 60 & 28.11 & 43 & Lymphocyte & Positive & NA & $\begin{array}{l}\text { Cryptococcus } \\
\text { neoformans }\end{array}$ \\
\hline $\begin{array}{l}\text { Yilmaz-Demirdag } \\
\text { et al. [24] }\end{array}$ & 175 & 44 & 75 & Neutrophils & Positive & $1: 1024$ & $\begin{array}{l}\text { Cryptococcus } \\
\text { neoformans }\end{array}$ \\
\hline Jha et al. [26] & 80 & NA & NA & NA & Positive & Positive & NA \\
\hline Salit et al. [27] & 227 & 65.88 & 126 & NA & NA & $1: 2048$ & $\begin{array}{l}\text { Cryptococcus } \\
\text { neoformans }\end{array}$ \\
\hline Lepur et al. [39] & 191.5 & 3.6 & 700 & Lymphocyte & Positive & NA & $\begin{array}{l}\text { Cryptococcus } \\
\text { neoformans }\end{array}$ \\
\hline Lepur et al. [29] & 155.5 & 10.8 & 450 & Neutrophils & NA & NA & $\begin{array}{l}\text { Cryptococcus } \\
\text { neoformans }\end{array}$ \\
\hline Cheung et al. [31] & NA & NA & 13 & Neutrophils & Positive & $1: 4.56$ & $\begin{array}{l}\text { Cryptococcus } \\
\text { neoformans }\end{array}$ \\
\hline C.L.HO et al. [32] & NA & 48 & 0 & 0 & NA & $1: 64$ & NA \\
\hline Yinnon et al. [33] & NA & NA & 87 & NA & NA & $1: 1024$ & $\begin{array}{l}\text { Cryptococcus } \\
\text { neoformans }\end{array}$ \\
\hline Ramirez et al. [34] & 20 & 68 & 0 & 0 & NA & $1: 1024$ & $\begin{array}{l}\text { Cryptococcus } \\
\text { neoformans }\end{array}$ \\
\hline Ostrowski et al. [35] & NA & NA & 98 & Lymphocyte & Positive & $1: 8192$ & $\begin{array}{l}\text { Cryptococcus } \\
\text { neoformans }\end{array}$ \\
\hline Duncan et al. [36] & 25 & 54 & 0 & 0 & Positive & $1: 8192$ & $\begin{array}{l}\text { Cryptococcus } \\
\text { neoformans }\end{array}$ \\
\hline Duncan et al. [36] & 172 & 48.96 & 68 & Lymphocyte & Positive & $1: 16,384$ & $\begin{array}{l}\text { Cryptococcus } \\
\text { neoformans }\end{array}$ \\
\hline
\end{tabular}

\section{Abbreviations}

ICL: Idiopathic CD4 + T lymphocytopenia; HIV: Human immunodeficiency virus; CSF: Cerebrospinal fluid; PCR: Polymerase chain reaction; CT: Computed tomography; MRI: Magnetic resonance imaging; mNGS: Metagenomic nextgeneration sequencing; GCS: Glasgow Coma Scale.

\section{Acknowledgements}

Not applicable.

\section{Authors' contributions}

LF conceptualized and designed case report with manuscript writing. JZ, FL were involved in the patient's care. All authors read and approved the final manuscript.

\section{Funding}

This work was supported by Zhejiang Medical and Health Science and Technology Program under Grant Number 2020KY604

Availability of data and materials

All data generated or analyzed during this study are included in this published article.

\section{Declarations}

\section{Ethics approval and consent to participate}

All patient details have been de-identified. The patient provide verbal informed consent. 


\section{Consent for publication \\ Not applicable.}

\section{Competing interests}

The authors declare no competing interests.

Received: 6 November 2021 Accepted: 10 February 2022 Published online: 05 March 2022

\section{References}

1. Yarmohammadi $\mathrm{H}$, Cunningham-Rundles C. Idiopathic CD4 lymphocytopenia: pathogenesis, etiologies, clinical presentations and treatment strategies. Ann Allergy Asthma Immunol. 2017;119(4):374-8.

2. Centers for Disease Control (CDC). Unexplained CD4+ T-lymphocyte depletion in persons without evident HIV infection-United States. MMWR Morb Mortal Wkly Rep. 1992;41:541.

3. Sloan DJ, Parris V. Cryptococcal meningitis: epidemiology and therapeutic options. Clin Epidemiol. 2014;6:169-82.

4. Rajasingham R, Smith RM, Park BJ, et al. Global burden of disease of HIV-associated cryptococcal meningitis: an updated analysis. Lancet Infect Dis. 2017;17:873-81.

5. Wilson LS, Reyes CM, Stolpman M, et al. The direct cost and incidence of systemic fungal infections. Value Health. 2002;5:26-34.

6. Gholamin M, Bazi A, Abbaszadegan MR. Idiopathic lymphocytopenia. Curr Opin Hematol. 2015;22:46.

7. Zonios DI, Falloon J, Bennett JE, et al. Idiopathic CD4+ lymphocytopenia: natural history and prognostic factors. Blood. 2008;112:287.

8. Ahmad DS, Esmadi M, Steinmann WC. Idiopathic CD4 lymphocytopenia: spectrum of opportunistic infections, malignancies, and autoimmune diseases. Avicenna J Med. 2013;3(2):37-47.

9. Browne SK. Anticytokine autoantibodies in infectious diseases: pathogenesis and mechanisms-ScienceDirect. Lancet Infect Dis. 2010;10(12):875-85.

10. Demir S, Chebib N, Thivolet-Bejui F, et al. Pulmonary alveolar proteinosis following cryptococcal meningitis: a possible cause? BMJ Case Rep. 2018. https://doi.org/10.1136/bcr-2017-222940.

11. Kuo CY, Wang SY, Shih HP, et al. Disseminated cryptococcosis due to anti-granulocyte-macrophage colony-stimulating factor autoantibodies in the absence of pulmonary alveolar proteinosis. J Clin Immunol. 2017;37:143-52.

12. Saijo T, Chen J, Chen SC, Rosen LB, Yi J, Sorrell TC, et al. Anti- granulocytemacrophage colony-stimulating factor autoantibodies are a risk factor for central nervous system infection by Cryptococcus gattii in otherwise immunocompetent patients. MBio. 2014;5(2):e00912-e914.

13. Sim BNH, Hui LY, Krishnan D, et al. Idiopathic CD4 lymphopenia in a case of disseminated cryptococcosis with brain, vertebral spine and reproductive organ involvement. Clin Med (Lond). 2019;19(2):133-4.

14. Eshwara VK, Garg R, Chandrashekhar GS, et al. Fatal Cryptococcus gattii meningitis with negative cryptococcal antigen test in a HIV-non-infected patient. Indian J Med Microbiol. 2018:36(3):439-40.

15. Malone C, Gupta ND, Kothari A, Palacios E, Neitzschman H. Radiology case of the month: idiopathic CD4 lymphocytopenia. J La State Med Soc. 2017:169(3):85-7.

16. Ayub MT, Jafar MS, Khalid M, et al. Suppressed without a cause: a case of idiopathic immune deficiency. Cureus. 2018. https://doi.org/10.7759/ cureus.2009.

17. Shribman S, Noyce A, Gnanapavan S, et al. Cryptococcal meningitis in apparently immunocompetent patients: association with idiopathic CD4+ lymphopenia. Pract Neurol. 2018;18:166-9.

18. Pavić I, Cekinović D, Begovac J, et al. Cryptococcus neoformans meningoencephalitis in a patient with idiopathic CD4+ T lymphocytopenia. Coll Antropol. 2013;37(2):619-23.

19. Sancesario G, Palmieri G, Viola G, et al. Difficulty diagnosing chronic cryptococcal meningitis in idiopathic CD4+ lymphocytopenia. Neurol Sci. 2011;32(3):519-24.
20. Tsalik EL, Jaggers LB. Life-threatening asymptomatic incidentaloma: a case report of idiopathic CD4 lymphocytopenia and opportunistic infections. Am J Med Sci. 2010;340(2):158-9.

21. Sharma A, Lal V, Modi M, et al. Idiopathic CD4 lymphocytopenia presenting as refractory cryptococcal meningitis. Ann Indian Acad Neurol. 2010;13(2):136-8

22. Augustine R, Khalid M, Misri ZK, et al. Idiopathic CD4+ T-lymphocytopenia-a diagnostic dilemma. J Assoc Physicians India. 2010;58:45-7.

23. Augusto E, Raguenaud ME, Kim C, et al. Idiopathic CD4+ T-lymphocytopenia with cryptococcal meningitis: first case report from Cambodia. Trop Doct. 2009;39(3):176-7.

24. Yilmaz-Demirdag Y, Wilson B, Lowery-Nordberg M, et al. Interleukin-2 treatment for persistent cryptococcal meningitis in a child with idiopathic CD4(+) T lymphocytopenia. Allergy Asthma Proc. 2008;29(4):421-4.

25. Juhi T, BibhaBati M, Aradhana B, et al. Cryptococcal meningitis in a tertiary care hospital. Nippon Ishinkin Gakkai Zasshi. 2009;50(2):95-9.

26. Jha S, Ghosh P, Agarwal V. Cryptococcal meningitis unmasking idiopathic CD4 Iymphocytopenia. Neurol India. 2007:55(3):312-4.

27. Salit RB, Hankey KG, Yi R, et al. Detection of CD4(+) T-cell antibodies in a patient with idiopathic CD4 T lymphocytopenia and cryptococcal meningitis. Br J Haematol. 2010;139(1):133-7.

28. Diamantis PK, Zacharenia S, Ireni K, et al. Idiopathic CD4+ T lymphocytopenia disclosed by recurrent cryptococcal meningitis. First case report from Greece. Int J Infect Dis. 2005;9:347-8.

29. Lepur D, Vranjican Z, Barsić B, et al. Idiopathic CD4+ T-lymphocytopenia-two unusual patients with cryptococcal meningitis. J Infect. 2005:51(2):E15-8.

30. Netea MG, Brouwer AE, Hoogendoorn EH, et al. Two patients with cryptococcal meningitis and idiopathic CD4 lymphopenia: defective cytokine production and reversal by recombinant interferon-gamma therapy. Clin Infect Dis. 2004;39(9):e83-7.

31. Cheung MC, Rachlis AR, Shumak SL. A cryptic cause of cryptococcal meningitis. CMAJ. 2003:168(4):451-2.

32. Ho CL, Chang BC, Hsu GC, et al. Pulmonary cryptococcoma with CD4 lymphocytopenia and meningitis in an HIV-negative patient. Respir Med. 1998;92:120-2.

33. Yinnon AM, Bernard R, Ephaim S, et al. Invasive cryptococcosis in a family with epidermodysplasia verruciformis and idiopathic CD4 cell depletion. Clin Infect Dis Off Publ Infect Dis Soc Am. 1997;5:1252-3.

34. Ramirez JA, Srinath L, Ahkee S, et al. HIV-negative "AIDS" in Kentucky: a case of idiopathic CD4+ lymphopenia and cryptococcal meningitis. South Med J. 1994:87(7):751-2.

35. Ostrowski M, Salit IE, Gold WL, et al. Idiopathic CD4+ T-lymphocytopenia in two patients. CMAJ. 1993:149(11):1679.

36. Duncan RA, von Reyn CF, Alliegro GM, et al. Idiopathic CD4+ T-lymphocytopenia-four patients with opportunistic infections and no evidence of HIV infection. N Engl J Med. 1993;328(6):393-8.

37. Zhu LP, Wu JQ, Xu B, et al. Cryptococcal meningitis in non-HIV-infected patients in a Chinese tertiary care hospital, 1997-2007. Med Mycol. 2010;48(4):570-9.

38. Chen $\mathrm{CH}$, Sy HN, Lin $L$, et al. Epidemiological characterization and prognostic factors in patients with confirmed cerebral cryptococcosis in central Taiwan. J Venom Anim Toxins Incl Trop Dis. 2015:21:12.

39. Pappas PG, Perfect JR, Cloud GA, et al. Cryptococcosis in human immunodeficiency virus-negative patients in the era of effective azole therapy. Clin Infect Dis. 2001;33(5):690-9.

40. Hung CW, Chang WN, Kung CT, et al. Predictors and long-term outcome of seizures in human immuno-deficiency virus (HIV)-negative cryptococcal meningitis. BMC Neurol. 2014;14:208.

41. Wu JQ, Xu B, Ou XT, et al. Factors associated with mortality in cryptococcal meningitis. Zhonghua Yi Xue Za Zhi. 2010;90(1):33-7.

42. Diamond RD, Bennett JE. Prognostic factors in cryptococcal meningitis. A study in 111 cases. Ann Intern Med. 1974;80(2):176-81.

43. Lee YC, Wang JT, Sun HY, et al. Comparisons of clinical features and mortality of cryptococcal meningitis between patients with and without human immunodeficiency virus infection. J Microbiol Immunol Infect. 2011;44(5):338-45.

44. Anekthananon T, Manosuthi W, Chetchotisakd P, et al. Predictors of poor clinical outcome of cryptococcal meningitis in HIV-infected patients. Int J STD AIDS. 2011;22(11):665-70. 
45. Cabello Úbeda A, Fortes Alen J, Gadea I, et al. Cryptococcal meningoencephalitis. Epidemiology and mortality risk factors in pre- and postHAART era. Med Clin (Barc). 2016;146(9):397-401.

46. Hakyemez IN, Erdem H, Beraud G, et al. Prediction of unfavorable outcomes in cryptococcal meningitis: results of the multicenter Infectious Diseases International Research Initiative (ID-IRI) cryptococcal meningitis study. Eur J Clin Microbiol Infect Dis. 2018;37(7):1241-2.

47. Zonios DI, Falloon J, Huang CY, et al. Cryptococcosis and idiopathic CD4 lymphocytopenia. Medicine. 2007;86(2):78-92.

\section{Publisher's Note}

Springer Nature remains neutral with regard to jurisdictional claims in published maps and institutional affiliations.

- fast, convenient online submission

- thorough peer review by experienced researchers in your field

- rapid publication on acceptance

- support for research data, including large and complex data types

- gold Open Access which fosters wider collaboration and increased citations

- maximum visibility for your research: over $100 \mathrm{M}$ website views per year

At BMC, research is always in progress.

Learn more biomedcentral.com/submissions 